\title{
10: $98021316-97941447$
}

National Cancer Institute

\section{Source}

National Cancer Institute. 10: 98021316-97941447. NCI Thesaurus. Code C41785.

Physical location of BLNK_Gene 